\title{
Children sharing preferences on contact and residence arrangements in child-inclusive family mediation in Norway
}

\author{
Lovise Grape \\ PhD candidate, RKNU North, UiT The Arctic University of Norway \\ Lovise.grape@uit.no
}

Renee Thørnblad

Professor, RKBU North, UiT The Arctic University of Norway

Renee.thornblad@uit.no

Bjørn Helge Handegård

Senior lecturer, RKBU North, UiT The Arctic University of Norway

Bjorn.helge.handegaard@uit.no

\begin{abstract}
Mediation is mandatory for all separating and divorcing parents in Norway with children under 16 years. The participation of children is voluntary. Living arrangement preferences presented by children attending child-inclusive family mediation in Norway ( $n=346$, aged 418 years) have been examined. $47.1 \%$ of children gave a living arrangement preference, and older children were more likely to express a preference for living primarily with the mother compared to an equal time-sharing arrangement. Children very often gave reasoned explanations for their wishes. Children's utilization of the potential in their participation support future inclusion of children in mediation processes. The best interest of the child needs to be examined on an individual basis as children present various preferences that is not in line with a presumption of fixed time-sharing following parental break-up.
\end{abstract}

\section{Keywords}

Custody arrangements, shared parenting, family mediation, children’s rights, child participation, mixed method 


\section{Introduction}

Parents have to make a decision regarding living arrangements following parental divorce and break-up. Children are supposed to be given the opportunity to participate in proceedings that lead to a reorganisation of the family. This is a right declared in Article 12 of the UN Convention on the Rights of the Child, which states that children should have the opportunity to express their views, and their views should be given due weight according to their age and maturity (UN General Assembly, 1989). The issue of divorce and separation is specified in the general comment No. 12 (UN Committee on the Rights of the Child, 2009: 15), which states that children have a right to be heard in any judicial or administrative proceedings that affects the child, such as court proceedings or mediation processes.

One of the main decisions in such proceedings is the child's residence and contact arrangement. Joint physical custody (JPC), also referred to as shared parenting and shared residence, is becoming increasingly common in Western countries (Steinbach, 2019). Internationally, JPC refers to children spending at least $25-50 \%$ of the time with each parent (Smyth, 2017). However, the criteria of JPC vary in different countries and studies. For instance, Nielsen (2018) used a criterion of at least 35\% of the time with each parent. In Norway, "shared residence" usually implies that the child spends approximately equal time with each parent, with both parents having an equal say concerning the child's everyday life (Kitterød and Lyngstad, 2014: 7). This meets the criteria of an equal time-sharing arrangement (ETSA). Research from Norway on the proportions of children with shared residence is therefore not directly comparable with other countries (Kitterød and Wiik, 2017). For instance, when Steinbach (2019) referred to Kitterød and Wiik (2017) as saying that the prevalence of JPC among Norwegian divorced families is about 30\%, this was somewhat misleading. With a considerable proportion of families reporting sole custody with one of the parents, there is at least 10 days contact with the non-resident parent each month (Kitterød 
and Lyngstad, 2014: 40), implying a higher percentage of broadly defined JPC. A “normal contact arrangement” is considered by practitioners in Norway to be up to a 65/35 time-share between the parents, e.g. one afternoon every week, sleepovers every other weekend, three weeks in the summer holidays, and every other Christmas, Easter, winter and autumn holidays with the non-custodial parent (Kitterød, Lidén, Lyngstad, and Wiik, 2016). Taking this into consideration, there has been an increase in the use of JPC, in Norwegian terms, for children after parental divorce or separation, from 8\% in 2002, and 10\% in 2004 to about 25\% in 2012 (Kitterød, Lyngstad, Lidén, and Wiik, 2015). JPC in international terms is far more common in Norway.

The main focus of research concerning JPC has been that of children's well-being in various living arrangements (Steinbach, 2019) and their experience of living with a shared parenting arrangement (Birnbaum and Saini, 2015). There are several challenges with doing research on living arrangements, some of which relate to the lack of a precise definition of JPC, samples, methods, contexts, outcomes, control variables and selectivity issues (Steinbach, 2019). Although JPC seems to be a promising arrangement that meets the needs of modern families, its positive and negative effects need to be further examined (Steinbach, 2019). The research should serve the best interest of all family members, including the child's interests which should also be taken into account (Steinbach, 2019).

International (Birnbaum and Saini, 2015) and Nordic (Lidén and Kitterød, 2019; Ottosen and Schwartz, 2013; Sigurdardóttir, Júlíusdóttir, and Pálsdóttir, 2018) studies on children's perspectives have focused on their experience of living in, or previously living with, shared residence. Other studies have focused both on children's experience of their ability to influence the arrangement (Berman, 2018; Gollop, Smith, and Taylor, 2000), or on what parents report about children’s influence (Haugen, Dyrstad, and Ådnanes, 2015). Haugen et al. (2015) encouraged the inclusion of children in the decision-making process 
where parents decide on residence and contact arrangements, as well as efforts to include children in studies assessing their influence on these decisions.

\subsection{Child participation in deciding on living arrangements following parental separation}

Some children do not want to participate in decision-making processes that relate to parents' separation and divorce (Birnbaum and Saini, 2012). However, many studies find that children want to be meaningfully involved in such decisions, including the creation of parenting plans (Birnbaum and Saini, 2012; Maes, De Mol, and Buysse, 2011; Thørnblad and Strandbu, 2018). This applies to some children in conflicted matters as well (Carson, Dunstan, Dunstan, and Roopani, 2018; Cashmore and Parkinson, 2008; Holt, 2018). Birnbaum and Saini (2012) pointed out that children emphasised a democratic process where their voices were equally weighted, their right for autonomy was considered, and where they were authentically involved as co-creators of parenting plans.

Children's feedback, when given in a formal setting, can give directions in further discussions between the parents following a divorce or separation, and it can help parents to learn something new about children’s perspectives (Ballard, Holtzworth-Munroe, Applegate, D'Onofrio, and Bates, 2013; McIntosh, Long, and Wells, 2009). It can also contribute to achieving an agreement between the parents (McIntosh, Wells, Smyth, and Long, 2008). Some children perceive their participation as an opportunity to change and obtain flexibility in the parenting plans, and still maintaining strong relationships to both parents (Graham, Fitzgerald, and Phelps, 2009). Children can be highly capable of expressing what they like and dislike about the arrangements (Gollop et al., 2000).

\subsection{The development of child-inclusive practice in out-of-court mediation in Norway}

The Norwegian child custody dispute resolution system consists of three tiers (Nylund, 2018). The first two (family mediation and pre-court mediation), both mandatory, are referred to as 
mediation in continuation and are carried out free of charge by the local Family Counselling Offices. The third tier is court-connected alternative dispute resolution processes, which in practice is mostly court-connected mediation (for a process overview, see James, Haugen, Rantalaiho, and Marples, 2010: 322; Nylund, 2018). This article concerns the first two tiers. Mandatory mediation in Norway concerns families with children under 16 years. Parents have to meet for at least one mediation session in the case of separation between cohabiting or married parents, or in the case of pre-court intervention when parents wish to petition the court for parental responsibility, legal custody or visitation rights; or when parents disagree about relocation (The Children Act, 1981; The Marriage Act, 1991). Between 2014 and 2017, the Family Counselling Offices received about 16,000 new mediation cases annually, with about 6000 married couples wanting to separate, 5000 cohabiting parents breaking up, and 5000 pre-court mediation cases (Bufdir, 2018, 2019a). In mandatory mediation, parents must make a written agreement about parental responsibility, physical custody and contact arrangement, in addition to other practical matters relevant to the best interests of the child.

Children's right to participate in relation to family break-up is specified in Norwegian legislation (The Children Act, 1981; section 31; The Constitution, 1814; section 104.1). The rationale is that hearing children in mediation is a tool to ensure children's right to be heard in matters concerning them (Ministry of Children and Families, 2018). The number of children who participated in mandatory family mediation has increased substantially from 7\% in 2014 (Bufdir, 2015) to 26\% in 2018 (Bufdir, 2019b). The initial increase followed the implementation and application of the Children in Mediation (CIM) model in some local Family Counselling Offices that started in 2012. Child-inclusive mediation invites the child directly into the process (McIntosh et al., 2008), and it can involve the child by having the mediator or a child-specialist interviewing the child separately, or by supporting the child in a 
conversation with the whole family (Birnbaum, 2009). The CIM model primarily introduces children between 7 and 15 years systematically into the mediation process in the first meeting. Figure 1 illustrates the CIM proceeding.

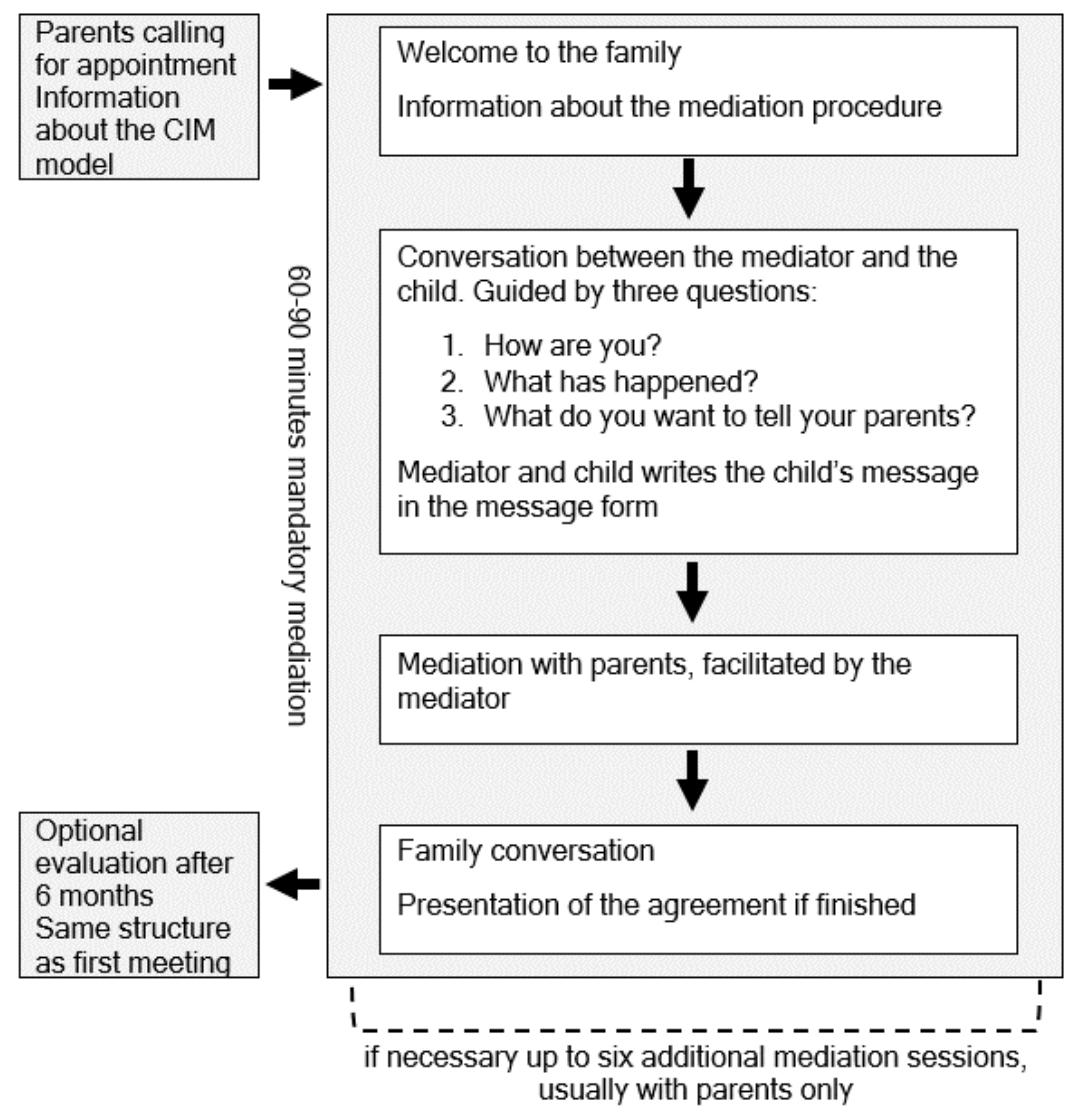

Figure 1 Procedure of the CIM model, as described by Jonassen (2016)

\subsubsection{The Hearing Children in Mediation (HCIM) project}

This paper is part of the HCIM project that carries out research on child-inclusive family mediation - specifically the CIM model - in a mandatory mediation setting in Norway. The research design has a convergent-parallel approach by combining qualitative and quantitative data (Thørnblad and Strandbu, 2018).

Previous project publications have examined children’s messages when participating in conversation with the mediator (Thørnblad and Strandbu, 2018), showing that children talk about their living arrangement preferences in relation to various topics. For instance, when commenting on ETSA, these are described as "fair", as solutions that enable frequent stays 
with each parent, with the emphasis on parents living near each other. Some talk about the difficulties with spending an equal amount of time at each parent's house due to a lack of friends at one of the places, and the difficulty of sharing themselves equally in a busy everyday life.

\subsection{Aims of this paper}

Children talked about their living arrangement preferences in the meeting with the mediator (Thørnblad and Strandbu, 2018), although this is not one of the guiding topics in the child conversation in the CIM model. To what extent children share their preferences when they attend mediation is generally unknown. This article aims to explore this aspect further by 1) what extent children want the mediator to share their living arrangement preferences with the parents when they participate in the context of the CIM model in Norway, and 2) whether children who prefer an ETSA differ significantly in terms of children's age, sex, or the level of conflict between the parents from those who have other preferences.

\section{Research design}

The research design of this study (outlined in Figure 2) is similar to a "Quasi-Mixed design" or "Monostrand Conversion design” (Teddlie and Tashakkori, 2006). The thick arrows indicate the main analytical path: how the child's message ends up as a quantitative outcome variable in the results section. The stippled arrows indicate how data constitute parts of the data collection, analytical, and inferential stages apart from the “data conversion”. The analysis was conducted in two phases, a content analysis of children's messages and a generalised linear mixed model analysis of associations between children’s living arrangement preferences and characteristics of the child or family conflict. The IBM SPSS Statistics 25 was used for the statistical work. 


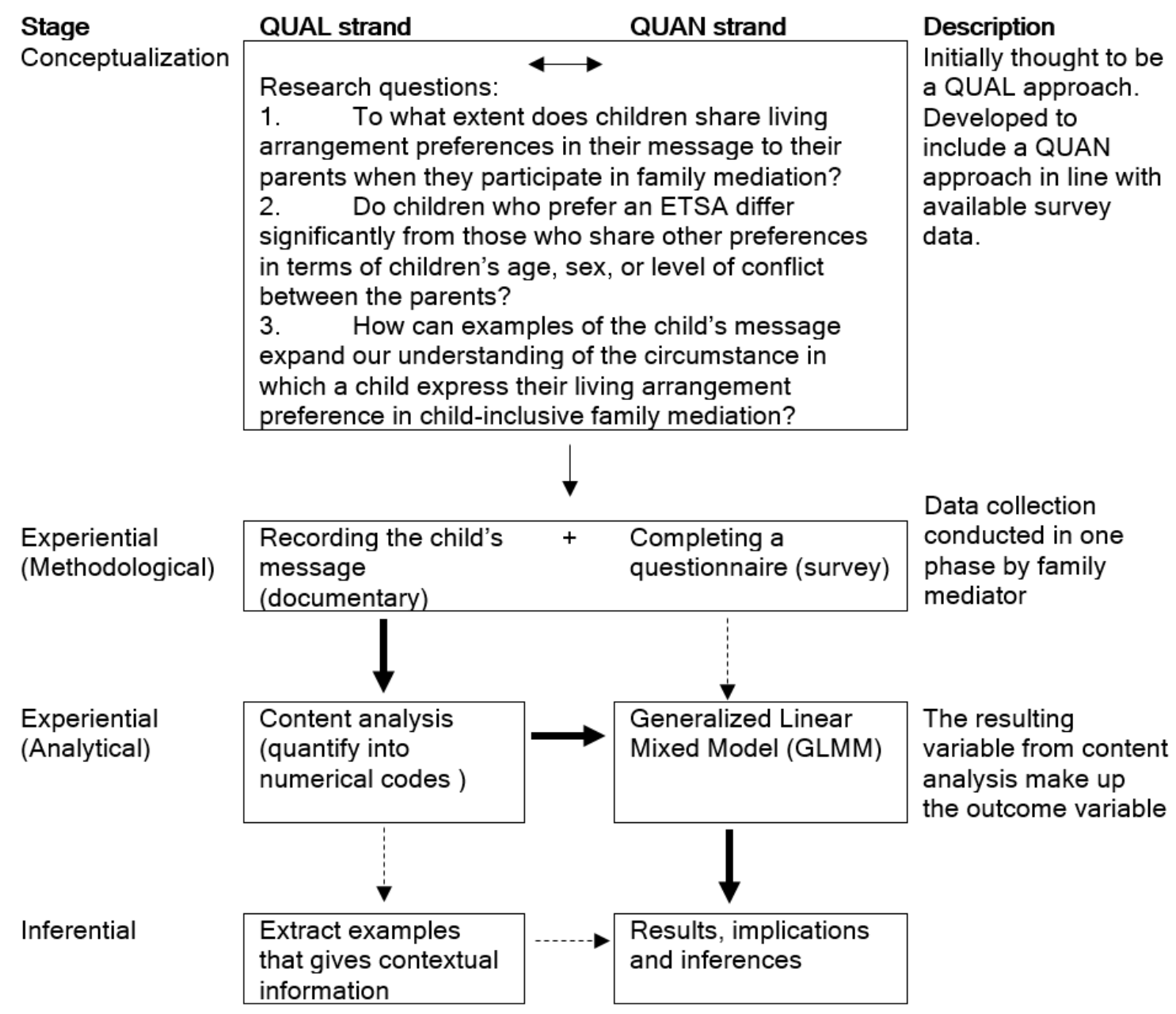

Figure 2 Outline of a Quasi-Mixed design

\subsection{Data collection}

The data collection followed the trial of the CIM model during the period of 2013-2015, where mediators at four Family Counselling Offices in two out of four regions in Norway contributed to the data collection of children's messages and questionnaires. All families obliged to attend family mediation at these offices in this period were offered child-inclusive mediation. Families who accepted the invitation were invited to participate in the research project. It was not possible to calculate a response rate due to the unknown number of families who were actually invited to bring the children with them and the unknown number of families who declined the invitation to participate in the research project. This is practice- 
based research based on self-selection, with mediators completing the forms immediately after the first mediation session.

At the first mediation session, 19 mediators (13 women and six men) contributed to the data collection. The mediators had between one and 46 cases each (mean $=11.3$ ). The occupation statuses of the mediators were: clinical psychologist, family therapist, social worker, child welfare officer, teacher, and theologian. All mediators had completed a formal mediator training with certification managed by the Norwegian Directorate for Children, Youth and Family Affairs. All mediators had considerable experience in working with family mediation. The mediators had completed training in the CIM model.

Table 1 Questionnaire content for the mediators at the mandatory family mediation session

\begin{tabular}{|c|c|c|}
\hline $\begin{array}{l}\text { Time } \\
\text { point }\end{array}$ & Measures and questions & \\
\hline \multirow{7}{*}{$\begin{array}{l}\text { First } \\
\text { mediation } \\
\text { session }\end{array}$} & Child’s message & $\begin{array}{l}\text { Message from children to parents provided to mediator } \\
\text { during child conversation }\end{array}$ \\
\hline & Characteristics & $\begin{array}{l}\text { Mediation type, children's age and sex, legal custody and } \\
\text { visiting arrangement, important aspects (e.g. substance } \\
\text { abuse, violence, psychiatry, child neglect, child protection } \\
\text { service, other aspects) }\end{array}$ \\
\hline & \multirow{5}{*}{$\begin{array}{l}\text { Single-item measure on a } \\
\text { scale, percentage score } \\
\text { Descriptions }\end{array}$} & Level of conflict \\
\hline & & Agreement between the parents \\
\hline & & Key features of the agreement \\
\hline & & Decisions in line with child's message \\
\hline & & Comments on important aspects \\
\hline
\end{tabular}

Table 1 shows the data collected by the mediators after the first mediation session. The single-items were scored on a visual analogue scale by the mediators, and responses were transformed into a score between 0 and 100. The questionnaires are short with no standardised and lengthy measures in order to make it convenient and less time-consuming for the mediators, young children and adolescents to complete the forms. 


\subsubsection{Sampling and sample characteristics}

All the families included in the study attended family mediation which was mandatory according to the statutory framework for parents who are separating, divorcing or in preadversarial proceedings. Parents are usually invited to bring children between seven and 15 to mediation applying the CIM model. Since these age limits are seen in light of children’s maturation, they are not strictly enforced. In some cases, both older or younger siblings wanted to participate. Therefore, families were included in the analysis irrespective of the children's ages. A total number of 213 families, with 346 children participated. Both parents were present in 207 of these families.

The average age of children (169 boys and 177 girls) participating in the first mediation was $10.8(S D=3.0)$, ranging from four to 18 years with an average number of 1.6 $(S D=0.7)$ children in each family. Family characteristics can be found in Table 2 .

Table 2 Characteristics of the families and children in the sample sorted by type of mediation

\begin{tabular}{lllcccccc}
\hline & $\mathrm{n}$ & Percent & \multicolumn{2}{c}{$\begin{array}{c}\text { Average age of } \\
\text { children }\end{array}$} & \multicolumn{2}{c}{ Average agreement } & Average conflict \\
& & & $\mathrm{N}$ & Mean $(S D)$ & $\mathrm{N}$ & Mean $(S D)$ & $\mathrm{N}$ & Mean $(S D)$ \\
\hline $\begin{array}{l}\text { Divorce mediation } \\
\text { Cohabitation break- }\end{array}$ & 94 & 44.1 & 167 & $11.4(3.1)$ & 88 & $84.7(22.4)$ & 92 & $22.8(26.1)$ \\
$\begin{array}{l}\text { up mediation } \\
\text { Pre-Court mediation }\end{array}$ & 64 & 24.9 & 85 & $9.6(2.8)$ & 52 & $84.6(21.5)$ & 53 & $27.2(28.8)$ \\
Total & 211 & 99.1 & 343 & & & & & \\
Missing & 2 & .9 & 3 & & 197 & & 205 & $69.7(30.0)$ \\
Total & 213 & 100.0 & 346 & $10.8(3.0)$ & 213 & & 213 & \\
\hline
\end{tabular}

Table 3 shows the agreements that parents made during the first mandatory mediation session, reported by the mediator. Lack of residence and contact arrangement registration was often due to parents writing the agreement at home, parental disagreement or because parents needed additional sessions. "Mostly one parent” refers to the time spent at the parent's place (up to a 65/35 time-share rate), and corresponds to what practitioners usually consider “normal contact”. "Only one parent” refers to no contact or less than normal contact with one of the parents. However only two children had no contact with the non-custodial parent. 
Table 3 Registered residence and contact arrangements after the first mandatory mediation session

\begin{tabular}{|c|c|c|c|c|c|c|}
\hline & & \multicolumn{5}{|c|}{ Contact arrangement } \\
\hline & & $\begin{array}{c}\text { Mainly one } \\
\text { parent }\end{array}$ & $\begin{array}{c}\text { Mostly one } \\
\text { parent }\end{array}$ & $\begin{array}{l}\text { Equal time } \\
\text { sharing }\end{array}$ & Not registered & Total \\
\hline \multirow{5}{*}{ 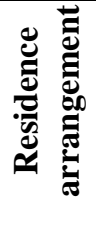 } & Mother & $29(8.4 \%)$ & 77 (22.3 \%) & $24(6.9 \%)$ & $4(1.2 \%)$ & $134(38.7 \%)$ \\
\hline & Father & $2(0.6 \%)$ & $18(5.2 \%)$ & $17(4.9 \%)$ & $2(0.6 \%)$ & 39 (11.3 \%) \\
\hline & ETSA & 0 & 0 & $111(32.1 \%)$ & 0 & $111(32.1 \%)$ \\
\hline & $\begin{array}{l}\text { Not } \\
\text { registered }\end{array}$ & 0 & 0 & 0 & $62(17.9 \%)$ & $62(17.9 \%)$ \\
\hline & Total & $31(9.0 \%)$ & $95(27.5 \%)$ & $152(43.9 \%)$ & $68(19.7 \%)$ & $346(100 \%)$ \\
\hline
\end{tabular}

\subsection{Content analysis}

The children's messages consist of key points from the child conversation. This is what the child and mediator agreed to communicate to the parents. The text is short in nature (see Table 4 for examples), and some might say that it does not fulfil the criteria for "qualitative data”, which is supposed to be characterised by reported speech and rich with a person's actions, expressions, intentions or perspectives (Thagaard, 2013). The text does not cover all aspects of the conversation, for instance topics discussed, but not written down.

However, for this purpose, the text represents an opportunity to gain insights into what children perceived as important for parents to know during the time of participation. The texts vary in how comprehensive they are. Living arrangements can be termed as 'linguistically constituted social realities that are rooted in the kinds of conversations that produced the texts' (Krippendorff, 2013: 80). Such a phenomenon is a good starting point for conducting content analysis. Content analysis is ‘a research technique for making replicable and valid inferences from texts (or other meaningful matter) to the contexts of their use' (Krippendorff, 2013: 24). By classifying qualitative data (in this case children's messages), one assumes that the meaning which is being described is in fact present in the material (Schreier, 2012). This was done in order to calculate frequencies and to do inferential statistics. According to Schreier (2012: 239), it 'does not make the method any less qualitative, [...] But one might argue that it turns the design of your study into a so-called mixed methods design'. 
The coding process applied principles from quantitative reliability testing and qualitative assessment of the coding frame and coding process. The coding frame was made by using definitions of JPC and ETSA: no preference, only one of the parents, mostly one of the parents, or ETSA (see Table 4). The coding frame was tested by the first and second author and a project professor who scored 30 children's messages from 20 families; refined criteria were then added.

Table 4 Coding frame of the content analysis

\begin{tabular}{|c|c|c|}
\hline Preference & Coding instruction & Example \\
\hline No preference & $\begin{array}{l}\text { No explicit information about } \\
\text { the child's preference of } \\
\text { residence or contact }\end{array}$ & $\begin{array}{l}\text { 'Boy wish that mother and father shall live close to } \\
\text { each other. Boy wants the family to celebrate } \\
\text { Christmas together'. }\end{array}$ \\
\hline $\begin{array}{l}\text { Only mother/ } \\
\text { father }\end{array}$ & $\begin{array}{l}\text { Minimal contact with the other } \\
\text { parent. Prefer to live with only } \\
\text { one parent. Can visit/meet the } \\
\text { other parent. Less than } 25 \% \text { of } \\
\text { the time with the non-custodial } \\
\text { parent. }\end{array}$ & $\begin{array}{l}\text { 'Wants to visit father in daytime, preferably outside - } \\
\text { eat and stuff, not staying overnights. Doing fine at } \\
\text { mum's'. } \\
\text { '[Boy’s name] wants to live with father in [name of } \\
\text { place]'. }\end{array}$ \\
\hline $\begin{array}{l}\text { Mostly mother/ } \\
\text { father }\end{array}$ & $\begin{array}{l}\text { Gives an example of more time } \\
\text { with one of the parents. At least } \\
25-49 \% \text { of the time with each of } \\
\text { the parents. }\end{array}$ & $\begin{array}{l}\text { 'Live two weeks with mother and one week with } \\
\text { father. Important that mother and father live close to } \\
\text { each other'. } \\
\text { 'Want to stay with father more. Want to stay with } \\
\text { mother also'. }\end{array}$ \\
\hline ETSA & $\begin{array}{l}\text { A specific preference of a } \\
\text { shared time arrangement that } \\
\text { equals to } 50 / 50\end{array}$ & $\begin{array}{l}\text { 'Want to try one week with both [parents]. It requires a } \\
\text { better relationship with his father. Otherwise he will } \\
\text { live with his mother'. }\end{array}$ \\
\hline
\end{tabular}

The first and second author conducted a test-retest reliability analysis. The preferred agreement criteria are a combination of Cohen’s Kappa and percent agreement, as suggested by (McHugh, 2012). The criteria of the Kappa was set to .60, which according to McHugh (2012: 279) correspond to a moderate level of agreement. A sufficient level of percent agreement was $80 \%$. We used SPSS to do a random selection of 15\% of the messages (apart from the 30 messages already assessed). The authors had all contextual information in the questionnaire (see Table 1) available in order to remove uncertainty. There was a moderate to strong agreement between the judgments of the two authors, $\mathrm{K}=.70$ (95\% CI, .50, .88), $p<.001$, raw percent agreement $=84.6 \%$. The authors reviewed the disagreements to 
establish a common understanding of the scores. The first author scored the rest of the messages.

The third step was conducted approximately seven months following the second step. The third author scored the messages that the first author scored alone $(n=268)$. The consistency was acceptable with $\mathrm{K}=.75$ (95\% CI, .68, .81), $p=<.001$, and raw percent agreement $=83.6 \%$. There were 44 disagreements that were reviewed and agreed upon .

\subsection{Applying generalised linear mixed models to assess associations between characteristics and preference}

The mediator did not always distinguish between the living arrangement preferences of siblings. We used a generalised linear mixed model to account for dependency across siblings’ arrangement preferences, assuming a multinomial distribution since living arrangement is categorical. Siblings share family and parent characteristics. Thus, a random intercept was included in the model to account for within family dependence. Children (level 1) were nested within families (level 2). The target variable was children's arrangement preferences. For the comparisons, a preference for an ETSA was used as reference target category.

The population characteristics of families in pre-court mediation cases differ from those in divorce and cohabitation mediation. Some of the differences relate to a higher level of conflict and a lower level of agreement, as can be seen in Table 2. Others relate to the time since the parents' break-up, and the time the children have lived with a certain living arrangement. Because the parents in these families are considering a court case, or possibly they already have been in court, it is less likely that these families have settled upon an ETSA (Andenæs, Kjøs, and Tjersland, 2017; Ministry of Children and Families, 2019). Because of these differences, we excluded families attending pre-court mediation from the analysis. Since 
we do not have any indications that families in divorce and cohabitation mediation differ on the general level, we carried out the analysis on both groups together.

The overall model included children's age and sex, level of agreement, and conflict. The method of variable selection was a backward stepwise selection process with the aim of finding significant contributors to the model. The variable with the highest significance probability of the fixed effects was removed in a stepwise order until there were only significant variables left. The significance level was set to .05.

\section{Results}

This part presents the findings from the content analysis, and the results from the generalised linear mixed model.

\subsection{Extent of living arrangement preferences in the child's message}

Although children were not asked about where they wanted to live, 47.1\% (163 children) wanted the mediator to communicate a living arrangement preference. Table 5 gives an overview of preferences sorted by mediation type. Children's messages written in pre-court mediation cases differ in one important way. Of the messages in pre-court mediation, $26.4 \%$ stated a preference for shared care out of all categories considered as JPC. However, very few messages were identified as stating a preference for ETSA.

Table 5 Expressed living arrangement preferences in the children's messages, as reported by children at mandatory mediation session

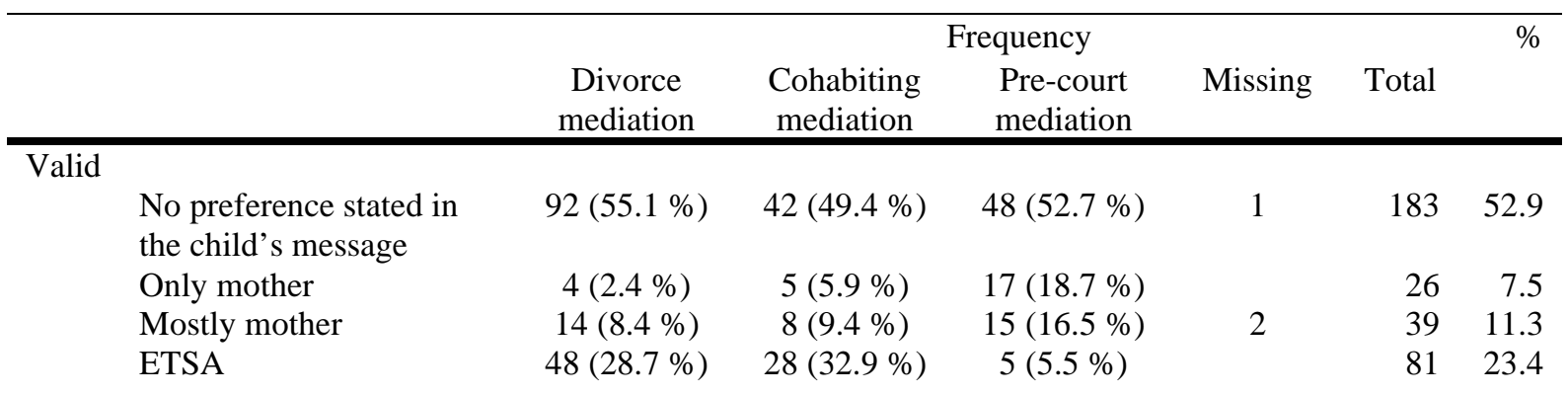


During the content analysis, it became clear that children very often gave an explanation or certain reservations in relation to the preferences stated. Material things and social relations such as closeness to school and friends, or more space where thematised. Also, justice, or what was fair, was given as an explanation, both for an ETSA and for justifying an unequal treatment of the parents.

The importance of maintaining strong relationships with both parents was a common explanation. Improvement of a relationship could be a requirement, or the concern that their wish to live more with one parent (often the mother) would harm the relationship with the other parent. A related theme, but somewhat distinct, was the behaviour of one parent concerning illness, harsh and vocal discipline, and issues with alcohol and other substances.

“The child's terms" was another theme. This could relate to the organising of the time with the non-custodial parent, the importance of convenient agreements, and acting in a flexible way. The following examples emphasise the need to assess the agreements at a later time-point: ' $\ldots$ but they need to change back to 50/50 for both, if it [the new arrangement] does not work' (siblings, cohabitation mediation) and '... What will happen if I am not satisfied with the agreement?' (adolescent, pre-court mediation).

\subsection{Associations with children's living arrangement preferences}

Due to few occurrences in "mostly father" and "only father”, these categories were merged for the analysis. Table 6 shows the backwards elimination process based on the total sample. The variable with the least significant value was removed in a stepwise procedure. The final model included the age of the child. Table 7 presents the specific comparisons. 
Table 6 Overall model of the total data set with fixed effects for included independent variables and backwards stepwise elimination procedure

\begin{tabular}{lllll}
\hline & Overall model & 1 & 2 & 3 \\
& $F(\mathrm{df} 1, \mathrm{df} 2)$ & $F(\mathrm{df1}, \mathrm{df2})$ & $F(\mathrm{df} 1, \mathrm{df} 2)$ & $F(\mathrm{df} 1, \mathrm{df})$ \\
\hline Corrected model & $1.05(16.218)$ & $1.30(12,222)$ & $1.79(8,237)$ & $2.90^{*}(4,244)$ \\
Age & $2.62 *(4,218)$ & $2.69 *(4,222)$ & $2.72 *(4,237)$ & $2.90^{*}(4.244)$ \\
Conflict & $.63(4,218)$ & $.62(4,222)$ & $.81(4,237)$ & \\
Agreement & $.54(4,218)$ & $.55(4,222)$ & & \\
Sex & $.35(4,218)$ & & & \\
${ }^{*} p<.05{ }^{* *} p<.01{ }^{* * *} \mathrm{p}<.001$ & & &
\end{tabular}

As can be seen in Table 6, age was the only variable that was significantly associated with type of preference stated in the child's message. Older children were more likely to state a preference for the majority of time at the mother's place when compared to an ETSA, with one year increase in age resulting in a $40 \%$ increase in the likelihood of the child's message including a preference for only living at the mother’s house. Age did not have a significant effect when comparing a preference for ETSA to the other categories.

Level of conflict was not significantly associated with children’s preferences. There was large variation in the level of conflict in each of the preference categories.

Table 7 Fixed coefficients viewed by prediction comparisons between categories in the target variable

\begin{tabular}{cllcccc}
\hline $\begin{array}{l}\text { Targeted } \\
\text { reference } \\
\text { category }\end{array}$ & $\begin{array}{l}\text { Compared target } \\
\text { categories }\end{array}$ & Independent variable & \multicolumn{3}{c}{ Coefficient } & \\
\\
\hline ETSA & Only mother & Age & Est. & $S E$ & $t$ & OR \\
& Mostly mother & Age & $.34 *$ & .17 & 2.03 & 1.404 \\
& Mostly and only father & Age & .09 & .09 & .99 & 1.097 \\
& No preference stated & Age & .25 & .14 & 1.84 & 1.288 \\
& & & -.08 & .06 & -1.32 & .919 \\
\hline Notes. ${ }^{*} p<.05$ & & & & & &
\end{tabular}

\section{Discussion}

Our study gives insights into the extent of children's emphasis on living arrangement preferences while attending family mediation. A special insight is that "shared care" is 
something different from an ETSA. As identified by qualitative studies on families living with an ETSA arrangement (see Birnbaum and Saini, 2015; Carson et al., 2018), children appreciate flexibility and being able to change arrangements, for instance to live longer periods with one of the parents if they think it is more practical or preferable. Adolescents especially seem to value flexibility, and are also more likely to obtain it as they become more independent and therefore able to move more easily between homes compared to younger children (Gollop et al., 2000; Lidén and Kitterød, 2019). Perhaps children, as they grow older, are more likely to view the arrangement of living more of the time with one parent as providing flexibility and enabling the child to continue with his or her developmental goals. From our rather small sample, we can find support for this tendency when looking at the effect of age in preferring to live "only” with mother. Although age was non-significant in the comparison between children preferring more time with their father and ETSA, it seems that the tendency is in the same direction for this group as well.

Our measures of conflict did not prove to have any effect on children's preferences in the analysis relating to children attending the first mandatory mediation session following parental separation or divorce. This was somewhat unexpected because few children in precourt mediation preferred an ETSA, and because researchers have argued that children are less satisfied with shared care arrangements when parents are in conflict (see Fehlberg, Smyth, Maclean, and Roberts, 2011; Lidén and Kitterød, 2019). One explanation might be that the broad definition of "shared care" was divided into sub-categories where ETSA is compared with mostly mother (different “shared care” arrangements compared with each other). A comparison between ETSA and “only mother” or “only father” might be more fruitful if the sample size were bigger. Another interpretation is that conflict between parents does not have an effect on children's preferences of ETSA during the family reorganisation. 
Rather, it might be the experience over time of living in two homes with conflicted parents that has an impact on where the child would like to live.

\section{Implications for practice and research}

We encourage family mediators to examine whether children want to share their preferences. After all, they are invited to a conversation that is part of a process where the parents are making an agreement about future living arrangements. They should not ask where the child wants to live. Being asked directly can put children in "a difficult position” (Cashmore and Parkinson, 2008). Rather, it is a question of whether to provide children with an opportunity to take a stand on this issue, which could clarify what having a say can be for that individual child. Although some mediators find it challenging to incorporate children's contribution to the decision-making process (Thørnblad, Strandbu, and Salamonsen, 2019), this topic provides an entry point into the child's life. Both an explanation for a preference and the lack of one provide an opportunity to engage in a dialogue that may later help the family in the reorganisation of post-separation family life.

Our findings do not suggest any "best arrangement practices”. However, few children in pre-court mediation in our study presented a preference for an ETSA. Any presumptions or hierarchical recommendations that suggest ETSA as being in the best interest of the child, risk to violate the views of children in contested matters'. Thus, children in our sample seem to support policy makers who favour assessments of the individual needs of children and families, and who argue against an ETSA for families characterised by conflict and where parents are unable to collaborate.

By applying a mixed approach to examining children’s messages when attending family mediation, we have been able to assess the written key points that resulted from the conversation between the mediator and the child. By quantifying the qualitative message into the operationalised living arrangements on three levels (equal, mostly and only), we were able 
to show the diversity within each category of children’s living arrangement preferences. Future studies that focus on "shared parenting” could benefit from applying similar categories when comparing child outcomes, and when looking at children's experiences of various living arrangements. "Shared parenting” alone makes up a broad category of living arrangements, and risks simplifying the context under which researchers draw conclusions with implications for children.

\subsection{Limitations}

Future studies might consider using established measurements for inter-parental conflict (e.g. Helland and Borren, 2015) for a more robust assessment of its impact for children’s living arrangement preferences. Also, due to the sample size, few children shared a preference for more time with the fathers compared with more time with their mothers, leading to lower power for analyses involving this category.

The content analysis is limited by the nature of the text in the message form. It is only what was expressed explicit that has been coded. The mediators' interpretations or what was said, but not written in the message form, have not been part of our data. Still, the written messages that were communicated to the parents by the mediator represent a unique insight into children's participation in the mediation process.

Caution is needed because our findings might be subject to selection bias as we have not measured control variables such as socio-economic status and response rate, and thus do not have information on how those who took part compared to those who did not. However, the size and composition of the selection make it probable that the results based on this sample have relevance beyond those that took part in this study (Thørnblad and Strandbu, 2018). Additionally, the cases collected in 2014 constituted $12 \%$ of the total number of mediation cases, and the percentage of pre-court mediation cases was very close to the national number (Thørnblad and Strandbu, 2018). This assumption is applied to our findings. 


\section{Conclusion}

We have pointed out that many children have an opinion of how family life following parental separation and divorce should be organised. We suggest that the CIM model provides a unique opportunity for the family and children to adapt arrangements to children's practical, emotional and psychological needs. Even though some children attending in the course of precourt mediation preferred shared care, few children shared a preference for ETSA. Older children were more likely to prefer living primarily with the mother compared to an ETSA. When these associations are seen in relation to the reasons and premises provided by children, and the analysis conducted by Thørnblad and Strandbu (2018), we can understand children’s living arrangement preferences in terms of children's need to be cared for and to belong to both parents and at the same time avoiding being forced into a fixed arrangement. This is in line with other research suggesting that it is the parenting styles and the quality of the parentchild relationship that have a bigger impact on children compared to the living arrangement (Smart, 2002; Smart and Neale, 2000). It is the emotional space, and not a shared time arrangement that provides security for children (Sadowski and McIntosh, 2016).

Because existing knowledge does not give any clear answers as to which living arrangement is in the best interest of the child, and because children have individual preferences and needs that cannot be fulfilled by a single solution, future policy making should avoid recommendations about any fixed percentages in living arrangements, especially for those proceeding to court. A focus on how practitioners can work with parents to increase flexibility and individual adjustments as the child's needs changes might be the most beneficial direction. And finally, many children do have the capacity to participate in decision-making processes, including the creation of parenting plans, if adults make adjustments for it to happen. 


\section{Acknowledgements}

Astrid Strandbu, Professor, Department of Education, UiT The Arctic University of Norway Anita Salamonsen, Professor, RKBU North, UiT Arctic University of Norway

Amy Holtan, Professor, RKBU North, UiT Arctic University of Norway

\section{Funding}

The data collection carried out in 2013-2014 was partly financed by Wøyenstiftelsen. The PhD-position is funded by RKBU North and the Faculty of Health Sciences at University of Tromsø. There were no dependencies or interest parties identified at the outset of the project.

\section{References}

Andenæs, A., Kjøs, P., and Tjersland, O. A., "Delt bosted - Hva sier forskningen? ”, Tidsskrift for Norsk Psykologforening, 2017 (54(3)), 276-283.

Ballard, R. H., Holtzworth-Munroe, A., Applegate, A. G., D'Onofrio, B. M., and Bates, J. E., “A randomized controlled trial of child-informed mediation”, Psychology, Public Policy, and Law, 2013 (19(3)), 271-281. DOI:10.1037/a0033274

Berman, R., "Children's influence on dual residence arrangements: Exploring decisionmaking practices”, Children and Youth Services Review, 2018 (91), 105-114. DOI:10.1016/j.childyouth.2018.05.038

Birnbaum, R., "Research Report: The Voice of the Child in Separation/Divorce Mediation and Other Alternative Dispute Resolution Processes: A Literature Review”. (Canada: Department of Justice Canada) 2009: https://www.justice.gc.ca/eng/rp-pr/fllf/divorce/vcsdm-pvem/pdf/vcsdm-pvem.pdf

Birnbaum, R., and Saini, M., “A qualitative synthesis of children's participation in custody disputes”, Childhood, 2012, (2(4)), 400-409. DOI:10.1177/1049731512442985

Birnbaum, R., and Saini, M., “A qualitative synthesis of children’s experiences of shared care post divorce”, The International Journal of Children's Rights, 2015 (23(1)), 109-132. DOI:10.1163/15718182-02301005

Bufdir, “Årsrapport 2014” 2015: https://www.bufdir.no/global/Arsrapport_2014_Bufdir.pdf Bufdir, “Årsrapport 2017” 2018: https://www.bufdir.no/arsrapport2017/

Bufdir, "Barn og samlivsbrudd”. 2019a: https://www.bufdir.no/Statistikk_og_analyse/Oppvekst/Familie_omsorg_og_relasjone r/Barn_og_samlivsbrudd/

Bufdir, “Årsrapport 2018” 2019b: https://www.bufdir.no/globalassets/documents/arsrapport2018.pdf

Carson, R., Dunstan, E., Dunstan, J., and Roopani, D., Children and young people in separated families: Family law system experiences and needs. (Melbourne: Australian Institute of Family Studies) 2018: https://aifs.gov.au/sites/default/files/publicationdocuments/1806_children_and_young_people_in_separated_families_report.pdf 
Cashmore, J., and Parkinson, P., “Children's and parents' perceptions on children's participation in decision making after parental separation and divorce”, Family Court Review, 2008 (46(1)), 91-104. DOI:10.1111/j.1744-1617.2007.00185.x

Fehlberg, B., Smyth, B., Maclean, M., and Roberts., C., "Legislating for Shared Time Parenting after Separation: A Research Review”, International Journal of Law, Policy and the Family, 2011 (25(3)), 318-337. doi:10.1093/lawfam/ebr015

Gollop, M. M., Smith, A. B., and Taylor, N. J., "Children's involvement in custody and access arrangements after parental separation”, Child \& Fam. LQ, 2000 (12(4)), 383-400.

Graham, A., Fitzgerald, R., and Phelps, R., "Final Report: The changing landscape of family law: exploring the promises and possibilities for children's participation in Australian family relationship centres”. (Lismore: Southern Cross University) 2009: https://epubs.scu.edu.au/cgi/viewcontent.cgi?article=1328\&context=educ_pubs

Haugen, G. M. D., Dyrstad, K., and Ådnanes, M., “SINTEF-A26769: Barns innflytelse på samværsordninger og bosted - Barns samvær og bosted i familier der foreldrene ikke bor sammen”. (Trondheim: SINTEF) 2015: https://www.sintef.no/globalassets/sintefteknologi-og-samfunn/rapporter-sintef-ts/rapport-a26769-endelig-rapport-barn-ogsamvar_bld.pdf

Helland, M. S., and Borren, I., “Rapport 2015:3: Foreldrekonflikt: identifisering av konfliktnivåer, sentrale kjennetegn og risikofaktorer hos høykonfliktpar” (Oslo: Folkehelseinstituttet) 2015: https://www.fhi.no/globalassets/dokumenterfiler/rapporter/2015/rapport-20153foreldrekonflikt-pdf.pdf

Holt, S., “A voice or a choice? Children's views on participating in decisions about postseparation contact with domestically abusive fathers", Journal of Social Welfare Family Law, 2018 (40(4)), 459-476. DOI:10.1080/09649069.2018.1519653

James, A. L., Haugen, G. M. D., Rantalaiho, M., and Marples, R., "The voice of the child in family mediation: Norway and England”, The International Journal of Children's Rights, 2010 (18(3)), 313-333. DOI:10.1163/157181810X494173

Jonassen, G., “Modell for barns deltakelse i meklingsprosessen”. (Grenland: Grenland familiekontor, Bufetat region sør) 2016: https://familieliv.no/wpcontent/uploads/88174-GFK-Hefte-BIM.pdf

Kitterød, R. H., Lidén, H., Lyngstad, J., and Wiik, K. A., Delt bosted for barna etter samlivsbrudd - en praksis for folk flest? Sosiologisk tidsskrift, 2016 (24(1)), 27-50.

Kitterød, R. H., and Lyngstad, J., "Discussion paper no. 780: Characteristics of parents with shared residence and father sole custody. Evidence from Norway 2012”. (Oslo:

Research Department, Statistics Norway) 2014: https://www.ssb.no/en/forskning/discussionpapers/_attachment/182569?_ts=14693e1b448

Kitterød, R. H., and Wiik, K. A., "Shared residence among parents living apart in Norway", Family Court Review, 2017 (55(4)), 556-571.

Kitterød, R. H. J., Lyngstad, J., Lidén, H., and Wiik, K. A., "Rapporter 2015/3: Praktiseres delt bosted for barn av andre foreldregrupper enn før?”. (Oslo: Statistics Norway) 2015: https://www.ssb.no/befolkning/artikler-ogpublikasjoner/_attachment/215361?_ts=14b07175a90

Krippendorff, K., Content analysis: An introduction to its methodology (3rd ed.) (Thousand Oaks, CA: Sage publications, 2013).

Lidén, H., and Kitterød, R. H. J., “Rapport 2019:3: Delt bosted: Barns perspektiver og utfyllende kunnskap”. (Oslo: Institutt for samfunnsforskning) 2019. 
Maes, S. D., De Mol, J., and Buysse, A., “Children’s experiences and meaning construction on parental divorce: A focus group study”, Childhood, 2011 (19(2)), 266-279. DOI:10.1177/0907568211421220

McHugh, M. L., "Interrater reliability: the kappa statistic”, Biochemia medica: Biochemia medica, 2012 (22(3)), 276-282.

McIntosh, J., Long, C. M., and Wells, Y. D., "Children beyond Dispute - A four year follow up study of outcomes from Child Focused and Child Inclusive post-separation family dispute resolution”. (Victoria, Australia: Family Transitions, 2009)

McIntosh, J. E., Wells, Y. D., Smyth, B. M., and Long, C. M., "Child-focused and childinclusive divorce mediation: comparative outcomes from a prospective study of postseparation adjustment”, Family Court Review, 2008 (46(1)), 105-124.

Ministry of Children and Families, "Tildelingsbrev til Barne-, ungdoms og familiedirektoratet”. 2018: https://www.regjeringen.no/contentassets/e3c03f39789d433a9ade95467740b6ab/bufdi r---tildelingsbrev-2019---endelig-versjon-19.12.2018.pdf

Ministry of Children and Families, "The child's place of residence and contact arrangements". 2019, 06.02.2019: https://www.regjeringen.no/en/topics/families-andchildren/innsiktsartikler/bosted-og-samvar/avtaler-om-fast-bosted-ogsamvar/id749587/

Nielsen, L., "Joint versus sole physical custody: Outcomes for children independent of family income or parental conflict”, Journal of Child Custody, 2018 (15(1)), 35-54. DOI:10.1080/15379418.2017.1422414

Nylund, A., “A dispute systems design perspective on norwegian child custody mediation”, in A. Nylund, K. Ervasti, \& L. Adrian (Eds.), Nordic Mediation Research (pp. 9-26). 2018. DOI:https://link.springer.com/book/10.1007\%2F978-3-319-73019-6

Ottosen, M. H., and Schwartz, R., "Beskyttelses-og risikofaktorer for skilsmissebørns trivsel i deleordninger”, Fokus på familien, 2013 (41(01)), 59-78.

Sadowski, C., and McIntosh, J., "On laughter and loss: Children's views of shared time, parenting and security post-separation”, Childhood, 2016 (23(1)), 69-86. DOI:10.1177/0907568215570072

Schreier, M., Qualitative content analysis in practice. (London: Sage Publications, 2012).

Sigurdardóttir, S., Júlíusdóttir, S., and Pálsdóttir, D., "Children’s voices on equal time-sharing arrangement following parents' divorce”, Journal of Social Welfare and Family Law, 2018 (40(2)), 164-180. DOI:10.1080/09649069.2018.1446710

Smyth, B. M., “Special Issue on Shared-Time Parenting after Separation”, Family Court Review, 2017 (55(4)), 494-499. DOI:https://doi.org/10.1111/fcre.12299

Steinbach, A., "Children's and Parents' Well-Being in Joint Physical Custody: A Literature Review”, Family Process, 2019 (58(2)), 353-369.

DOI:https://doi.org/10.1111/famp.12372

Teddlie, C., and Tashakkori, A., “A general typology of research designs featuring mixed methods”, Research in the Schools, 2006 (13(1)), 12-28.

DOI:10.1177/2345678906293042

Thagaard, T., “Den kvalitative metodens egenart”, in T. Thagaard (Ed.), Systematikk og innlevelse (4 ed., pp. 11-36). (Bergen: Fagbokforlaget, 2013).

The Children Act, (1981). Act of 8 April 1981 No. 7 relating to Children and Parents. Retrieved from https://www.regjeringen.no/en/dokumenter/the-children-act/id448389/

The Constitution, (1814). The Constitution of the Kingdom of Norway 17 May 1814. Retrieved from https://lovdata.no/dokument/NL/lov/1814-05-17-nn\#KAPITTEL_5

The Marriage Act, (1991). The Marriage Act (4 July 1991 No. 47). Retrieved from https://lovdata.no/dokument/NL/lov/1991-07-04-47 
Thørnblad, R., and Strandbu, A., "The involvement of children in the process of mandatory family mediation” in A. Nylund, K. Ervasti, \& L. Adrian (Eds.), Nordic Mediation Research (pp. 183-208). 2018. DOI:https://link.springer.com/book/10.1007\%2F978-3319-73019-6

Thørnblad, R., Strandbu, A., and Salamonsen, A., "Hvordan påvirker barns deltakelse foreldremekling? Barns deltakelse som mål og middel”, Barn, 2019 (37(2)), 67-80. DOI:https://doi.org/10.5324/barn.v37i2.3087

UN Committee on the Rights of the Child, "General Comment No. 12 (2009): The right of the child to be heard". 2009: http://www2.ohchr.org/english/bodies/crc/docs/AdvanceVersions/CRC-C-GC-12.pdf.

UN General Assembly, “The United Nations Convention on the Rights of the Child”. (New York: The United Nations, 1989) 